\title{
Dança no CEFD: da formação em Educação Física à criação de um Curso de Graduação em Dança
}

\author{
Dance at CEFD: from Physical Education undergraduate degree to the creation of a Dance \\ undergraduate course
}

Danza en CEFD: desde la formación en Educación Física hasta la creación de un Curso de Grado en Danza

\author{
Gustavo de Oliveira Duarte, Marcia Gonzalez Feijón ${ }^{\mathrm{III}}$, Luciane Sanchotene Etchepare Daronco ${ }^{\mathrm{III}}$, \\ Mara Rubia Alves da Silva ${ }^{\text {IV }}$
}

\begin{abstract}
Resumo
Este artigo apresenta como objetivo, além de homenagear o cinquentenário do Centro de Educação Física e Desportos (CEFD) da Universidade Federal de Santa Maria, contextualizar, registrar e refletir acerca das questões de formação em Dança e seus desdobramentos, a partir da área da Educação Física e, mais recentemente, da área de Artes. Os saberes autobiográficos são apresentados em forma de registros escritos e de imagens, assim como os atravessamentos do trabalho artístico-pedagógico realizado por participantes, acadêmicos, professores, pesquisadores, que fizeram parte desse processo histórico construído por essas duas áreas, nesta mesma instituição. Aponta perspectivas e possibilidades da consolidação da área de Dança no Centro de Educação Física e Desportos a partir da formação e da produção comunitária e acadêmica dos docentes que a constituíram até a atualidade.
\end{abstract}

Palavras-chave: Dança; Formação; Educação Física

\begin{abstract}
This present article aims to honor the 50th anniversary of the Physical Education undergraduate course and Sports Center of the Federal University of Santa Maria (UFSM) and contextualize, record, and reflect on the issues of the undergraduate degree in Dance and its consequences, starting from the field of Physical Education and, more recently, the Arts field. The autobiographical data are presented into written records and images forms, as well as the artistic-pedagogical work crossings carried out by participants, academics, teachers, and researchers who were part of this historical process built by these two fields of UFSM. Moreover, this article highlights perspectives and possibilities for Dance consolidation at Physical Education and Sports Center based on the community and academic production od professors who constituted it until today.
\end{abstract}

Keywords: Dance; Undergraduate Degree; Physical Education

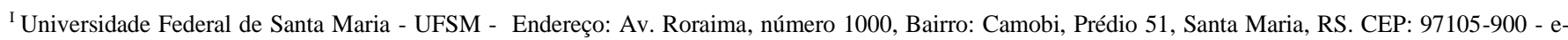
mail: guto.esef@gmail.com

${ }^{\text {II }}$ Universidade Federal de Santa Maria - UFSM - e-mail: marcgfa1@gmail.com

III Universidade Federal de Santa Maria - UFSM - e-mail: lusanchotene@ufsm.br

${ }^{\text {Iv }}$ Universidade Federal de Santa Maria - UFSM - e-mail: rubiaufsm@hotmail.com
} 


\section{Resumen}

El artículo presenta como objetivo, además de rendir homenaje al 50 aniversario del Centro de Educación Física y Deportes (CEFD) de la Universidad Federal de Santa María, contextualizar, registrar y reflexionar sobre los temas de la formación en Danza y sus consecuencias, desde el área de Educación Física y, más recientemente, el área de Artes. Los saberes autobiográficos se presenta en forma de registros e imágenes escritas, así como los cruces del trabajo artístico-pedagógico realizado por participantes, académicos, docentes, investigadores, que formaron parte de este proceso histórico construido por estas dos áreas, en esta misma institución. Apunta perspectivas y posibilidades para la consolidación del área de Danza en el Centro de Educación Física y Deportes partiendo de la formación y de la producción comunitaria y académica de los docentes que lo han constituido hasta el día de hoy.

Palabras clave: Danza; Formación; Educación Física

\section{Introdução}

O presente texto busca, além de homenagear o cinquentenário do Centro de Educação Física e Desportos (CEFD), contextualizar e refletir sobre as relações entre a formação inicial e continuada da área da Educação Física e as experiências no campo da Dança, seus limites, possibilidades e perspectivas. Pretendemos, também, como participantes do processo histórico deste Centro, tanto como alunos/as e atualmente como professores/as e pesquisadores/as, registrar o protagonismo e a relevância de todo um trabalho pedagógico, artístico e de formação de várias gerações de professores/as de Educação Física que trabalham/trabalharam como bailarinos/as e como professores/as com o ensino de Dança na Escola, e fora dela, sobretudo no Estado do Rio Grande do Sul, e registrar e refletir sobre as perspectivas de trabalho da nova geração de Professores/as licenciados/as em Dança, formados/as pelo CEFD da Universidade Federal de Santa Maria.

Tratar da Dança no CEFD é também tratar da Dança na cidade de Santa Maria/RS e, de certa forma, no Estado do Rio Grande do Sul. É tratar de uma diversidade de técnicas e de metodologias de ensino e da cena artística acerca do corpo, do movimento humano, das capacidades do sentir e do expressar e, também, da busca da tão almejada Educação Estética (HASELBACH, 1995; FEIJÓ, 1996; DUARTE, 2007). Também é refletir sobre as relações com a vivência e com o ensino das chamadas técnicas codificadas, como o Balé Clássico, o Jazz-dance, as Danças Folclóricas e Tradicionais Gaúchas, as Danças de Salão, e, sobretudo, sobre o ensino da Dança para crianças e adolescentes, os processos criativos e educativos em dança, a chamada "Dança Criativa", Dança-Educação, a Dança Educativa Moderna (LABAN, 1990; MARQUES, 1999).

Nesse sentido, este texto busca registrar e refletir criticamente sobre o percurso histórico da Dança no CEFD a partir de registros e análise documental, de acervos pessoais, entrevistas, registros fotográficos e fílmicos, projetos e eventos realizados sobre a temática ao longo destes cinquenta anos de 
existência. Em um primeiro momento, contextualizar-se-ão as principais ações em dança desenvolvidas por docentes e alunos/as do Curso de Educação Física e, em um segundo momento, os desdobramentos da formação específica em Dança Licenciatura, a partir do novo cenário da criação de uma graduação em Dança. Tratar da Dança no CEFD é dar voz, é dar corpo, a várias gerações de bailarinos/as e suas respectivas produções artísticas e pedagógicas. É também visibilizar diferentes ações de professores/as que seguiram ensinando a Dança nas Escolas, seja na sociedade gaúcha e/ou brasileira.

\section{Frestas da Memória: pioneirismo e formação em Dança}

Os primeiros registros de apresentações de Dança no CEFD datam do ano de 1978, sob a orientação da Professora Jacira Paixão. O Professor Ruy Jornada Krebs também colaborou com a Dança na coreografia intitulada “A evolução da Dança”. Esse contexto foi caracterizado pela influência dos saberes da Ginástica Rítmica Desportiva e Ginástica Olímpica/Ginástica Artística. Nessa época, no currículo eram obrigatórias as disciplinas de Rítmica I e II e Ginástica I e II. Após a aposentadoria da Professora Jacira Paixão, a Professora Mara Rubia Alves da Silva assumiu as disciplinas de Ginástica e de Dança e Atividades Rítmicas no CEFD até sua aposentadoria; após, liderou a criação do Curso de Dança Licenciatura no CEFD.

Figura 1 - Grupo de Danças da UFSM. Coreografia: “A evolução da Dança”, Santa Maria/RS, 1978.

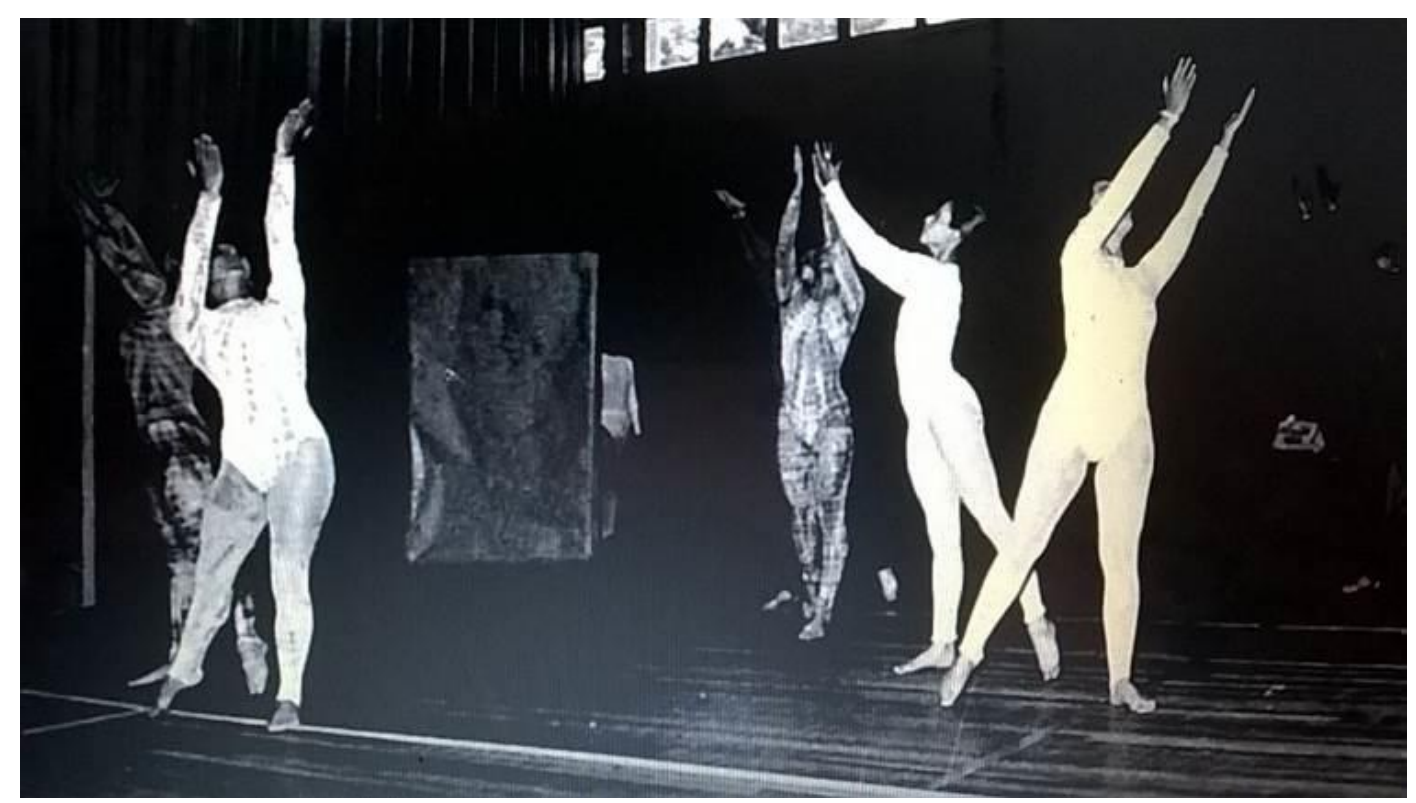

Fonte: Acervo de Jacira da Silva Paixão. 
Figura 2 - Grupo de Danças da UFSM. Coreografia: “A evolução da Dança”, Santa Maria/RS, 1978.

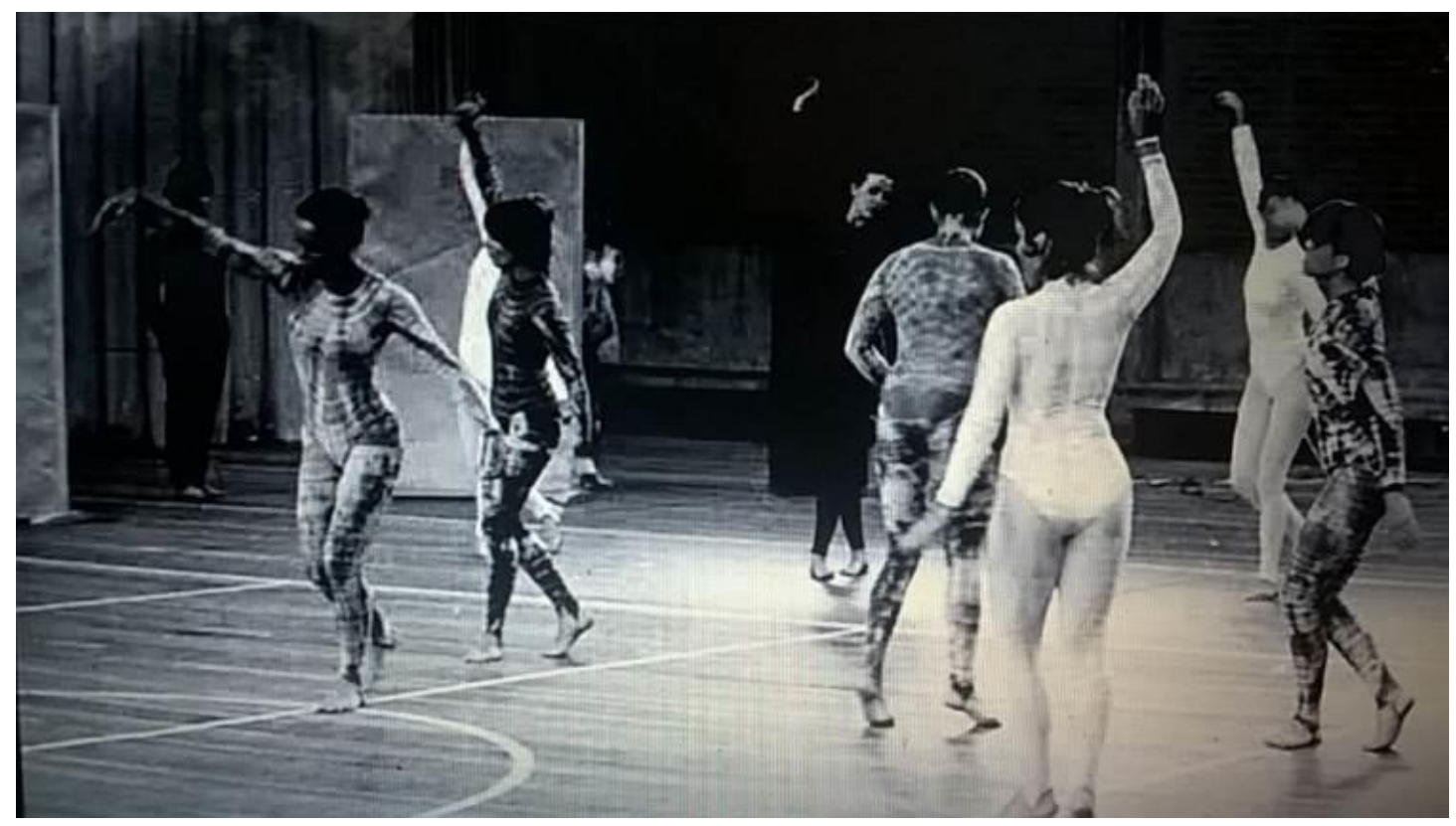

Fonte: Acervo de Jacira da Silva Paixão.

Em 1990 foi criado, oficialmente, o Grupo Universitário de Dança, carinhosamente chamado de GUD, sob a orientação da Professora Mara Rubia, para todos/as que buscavam aprofundar seus estudos em Dança. Luciane Sanchotene e Gustavo Duarte atuaram como bailarinos e coreógrafos no GUD.

Ex-aluna do Curso de Educação Física do CEFD, Mara Rubia Alves da Silva ingressou como professora no CEFD no ano de 1982, totalizando trinta e cinco anos de docência até sua aposentadoria em 2017. Atuou nas áreas de Ginástica, Atividades Rítmicas e Dança, com todas as faixas etárias. Podemos destacar suas relevantes contribuições na criação do Grupo "Extremus" - dança em cadeiras de rodas, onde acolheu pessoas com diferentes deficiências, e também no trabalho de dança com idosos/as. A professora Mara relata o crescimento da área de estudos em Dança no CEFD, onde, apesar dos traços de conservadorismo e machismo da região Sul do Brasil, a participação e conscientização dos homens na Dança foram consideráveis. Relata-nos que vários de seus ex-alunos, homens, passaram a trabalhar com dança em sua vida profissional, sobretudo com a Dança criativa com crianças.

A professora Mara Rubia investiu em sua formação continuada em dança buscando aperfeiçoamento em estudos de balé clássico, artes cênicas e folclore brasileiro. Seu Doutoramento, na Faculdade de Motricidade Humana (FMH), em Lisboa, Portugal, tratou da relação entre a mulher e as danças folclóricas portuguesas. A seguir abordaremos as contribuições de alguns profissionais da Dança, as/os quais foram alunas/os da professora Maria Rubia e seguiram atuando na dança, seja como 
bailarinas/os e/ou como docentes, dentre as/os quais, Marcia Feijó, Luciane Sanchotene e Gustavo Duarte foram aprovados em concursos públicos e atuam como docentes no CEFD.

Marcia Feijó foi acadêmica do Curso de Educação Física - Licenciatura Plena. Teve como ênfase em seus estudos acadêmicos a ginástica e a dança. Atuou em várias academias e escolas de dança da cidade de Santa Maria/RS como professora de dança, bem como bailarina e coreógrafa de grupos dessa cidade. Foi aluna do Ballet Ivone Freire onde estudou ballet por muitos anos. Teve a dança como tema central de suas experiências corporais e de suas pesquisas em sua passagem pela pós-graduação. Na Especialização em Pesquisa e Ensino do Movimento Humano pesquisou “A Expressão e o Movimento no Desenvolvimento da Dança de Crianças em Santa Maria - RS”, em 1992; no Mestrado, “A Dança como conteúdo Integrante da Educação Física Escolar enquanto Corporeificação de um Mundo sensível”, em 1997, sob orientação da Professora $\operatorname{Dr}^{\mathbf{a}}$ Ingrid Marianne Baecker. Obteve uma formação de Aperfeiçoamento em Bailarino para Corpo de Baile, na Escola Artístico Cultural Pirassununga, EACP, Brasil, 1997. Realizou seu Doutorado em Educação, na linha de Educação e Artes do Centro de Educação da Universidade Federal de Santa Maria, com temática em Dança, com a tese intitulada: "Dança Moderna e Pilates: um estudo sobre tradição, narração e práticas pedagógicas". Atualmente é professora no CEFD no Curso de Dança Licenciatura e no Curso de Educação Física.

Em 1992, Luciane Sanchotene ingressou no Centro de Educação Física e Desportos da UFSM, a mesma já atuava como professora de Jazz e Samba no Clube Recreativo Dores, função que exerceu de 1990 a 2005. Lá organizou Mostras de dança com a participação de Escolas Municipais, Estaduais e particulares. Trabalhou em colaboração com as Professoras, também formadas em Educação Física, Alessandra Londero e Tatiana Jardim. Essas possuem um longo percurso na Dança e continuam, até hoje, atuando no ensino de Dança, seja dentro ou fora da Educação Básica, e fazem parte da ADASM Associação de Dança de Santa Maria/RS. De 1992 a 1993 integrou um Grupo Experimental coordenado pelo Prof. Cergui Lima, o qual contribuiu significativamente tanto nas áreas de preparação corporal para a dança quanto em laboratórios de criação. Nesse período também atuou no grupo “Afrontações” de Dança Afro, coordenado pela professora Angela Lena, e no grupo de dança do Professor Arabutan Lima. Além de bailarina, Luciane Sanchotene atuou como pesquisadora, de 1993 a 1995, período em que fez parte de um grupo de estudos de Dança e Aprendizagem Motora, coordenado pelo professor Jefferson Thadeu Canfield. Atuou em diferentes escolas com o ensino de dança para crianças e adolescentes. Em 2005 foi aprovada no concurso para docente do CEFD/UFSM e em 2006 criou o GEDES (Grupo de Estudos da Dança), do qual resultaram vários trabalhos de dança tanto na Graduação como na Pós-Graduação do CEFD. 
No ano de 2009, a professora Luciane reativava oficialmente o projeto de extensão "Dançando no Campus", com aulas gratuitas de dança para a comunidade de Santa Maria/RS.

Figura 3 - Logotipo do Projeto Dançando no Campus

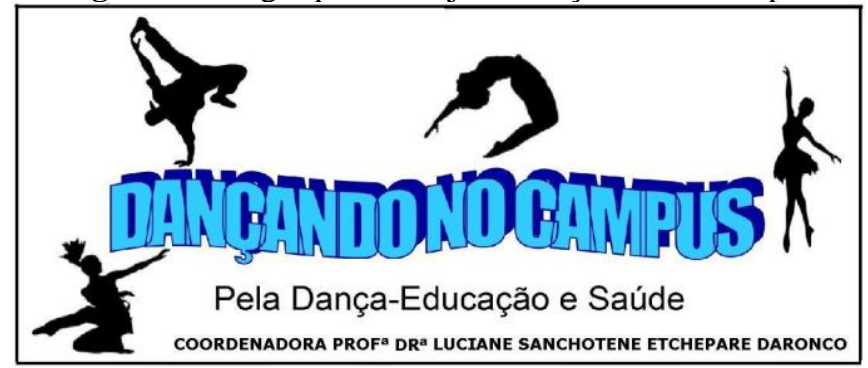

Fonte: Acervo de Luciane S. E. Daronco.

No ano seguinte, foi criada a primeira Companhia de Dança da UFSM para representar a mesma em Festivais e eventos de Dança fora da cidade, a UNIDANÇA, coordenada pela professora Luciane.

Figura 4 - Logotipo da UNIDANÇA

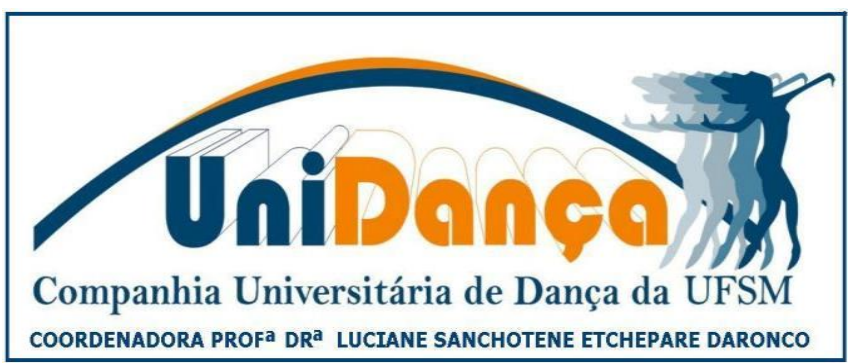

Fonte: Acervo de Luciane S. E. Daronco.

Figura 5 - Coreografia: “Tudo ou Nada”. Coreógrafa: Luiza Alejarra Peixe. Bailarinos(as): Andressa Ferreira da Silva, Anelise Seer Splett, Carolina Alegranzi, Gabrielle Barcelos, Juliano Peranzoni, Luiza Alejarra Peixe, Suzi Costa, Taíssa Menezes e Winnie Silva da Silva. Santa Maria/RS, 2012.

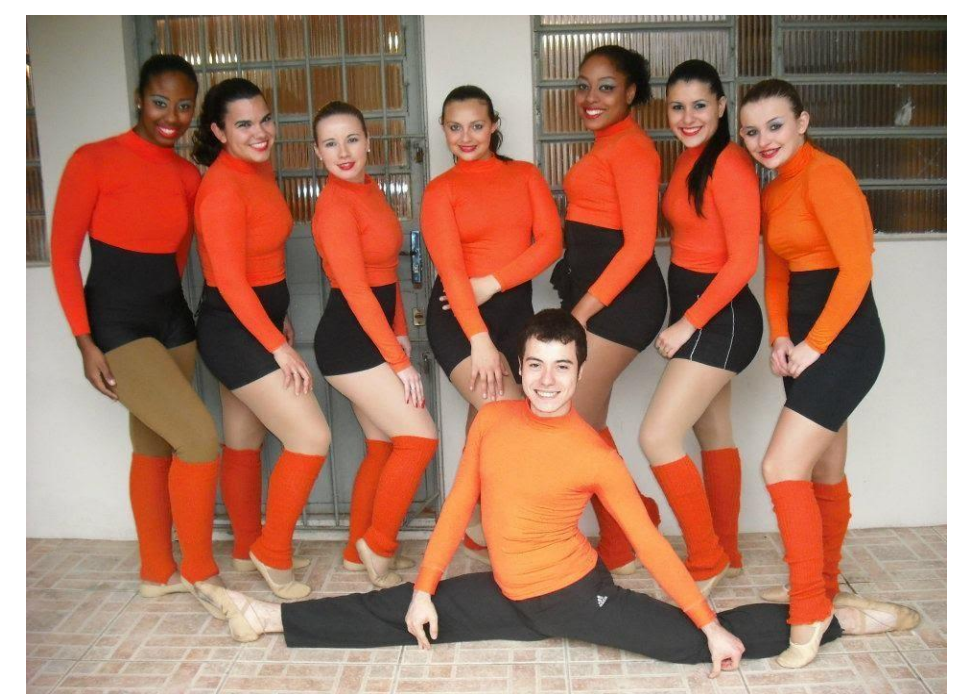

Fonte: Acervo de Luciane S. E. Daronco. 
Em 2013, a Professora Luciane criou a SEDA - Sociedade para Estudos da Dança, com professores de Dança do Rio Grande do Sul, Santa Catarina, Rio de Janeiro e Paraná, cujo foco foi a Dança no contexto escolar.

Em 2014, alunos provenientes do Centro de Artes e Letras ingressaram no GEDES, e a partir de então o mesmo passou a ser chamado de GEDEAS (Grupo de Estudos da Dança: Educação, Arte e Saúde).

Figura 6 - Logotipo do GEDEAS.

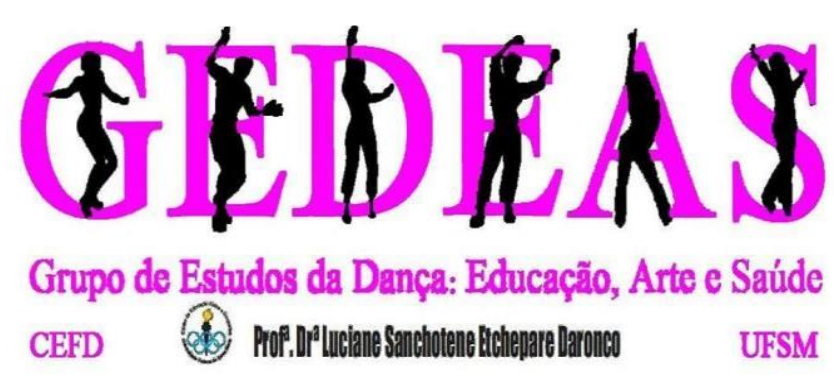

Fonte: Acervo de Luciane S. E. Daronco.

Dentre outros temas, professora Luciane visou ilustrar algumas questões importantes, como: a História da Dança, a Dança Adaptada, assim como a Dança-Educação e a Dança-Saúde. Tal interesse resultou na publicação de um livro de Dança produzido e inspirado integralmente nos projetos do CEFD/UFSM. Os estudos para a elaboração desse livro começaram em 2013 e o lançamento oficial da obra se deu em 2017. Com o título "Entendendo a Dança-Educação e Saúde em Diferentes Contextos”, o livro ofereceu a união de diversos referenciais, distribuídos em temas que cercam a Dança.

Figura 7 - Capa do livro “Entendendo a Dança-Educação e Saúde em Diferentes Contextos”.

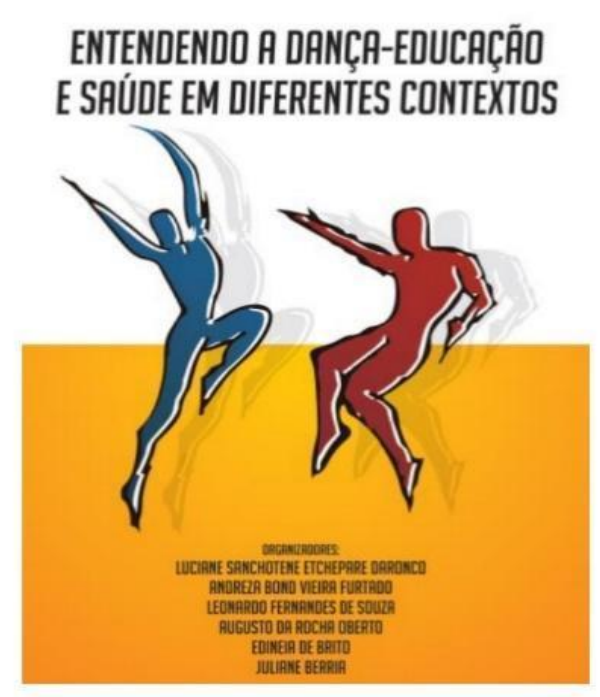

Fonte: Acervo de Luciane S. E. Daronco. 
A seguir, apresentamos as contribuições de outra artista da Dança, formada pelo CEFD. Angela Garcia ingressou no Curso de Educação Física em 1992 e também participou como bailarina e coreógrafa do Grupo Universitário de Dança e de inúmeras ações da dança no CEFD e na cidade de Santa Maria. Coordenou o Projeto de Extensão "Dançar", no ano de 1996, no Centro de Atendimento Integral à Criança (CAIC), localizado na vila Lorenzi. Em 1999 ingressou como docente no Curso de Educação Física da ULBRA, em Canoas/RS, onde atuou com Dança e organizou diferentes Mostras e Festivais de Dança. Cursou Mestrado em Ciência do Movimento Humano no CEFD, sob a orientação do ilustre Professor Ruy Jornada Krebs, com a pesquisa “A Dança como Contexto de Desenvolvimento de Meninas Adolescentes", em 2000. Atualmente, Angela é professora do Curso de Educação Física na SOGIPA, em Porto Alegre/RS, onde continua com o trabalho de Dança, Improvisação e Atividades Rítmicas.

Figura 8 - Coreografia: "Movimentos". Apresentação do Projeto Dançar na Escola CAIC, Santa Maria/RS, 1996.

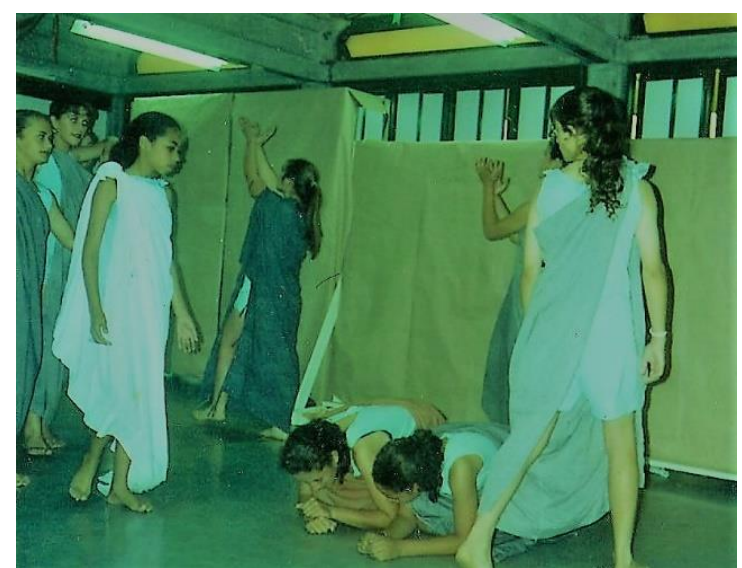

Fonte: Acervo de Angela Garcia.

Figura 9 - Espetáculo: Abstrações e Etc: o Universo Sensível de uma Dança Adolescente. Theatro Treze de Maio, Santa Maria/RS, 1997.

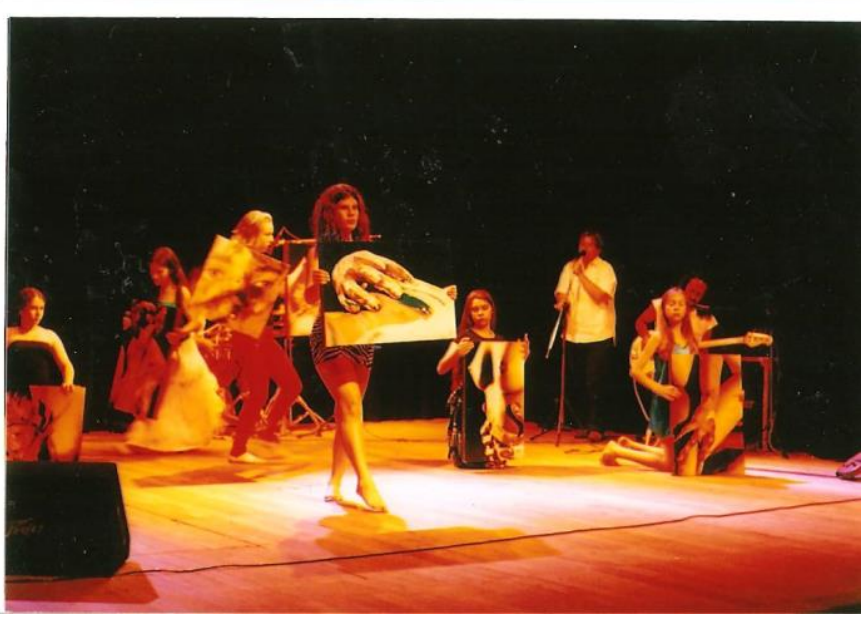

Fonte: Acervo de Angela Garcia. 
Na sequência apresentamos as contribuições de outro ex-aluno do CEFD e, atualmente, professor. Gustavo Duarte ingressou no Curso de Educação Física, Licenciatura Plena na época, em 1995 e iniciou seus estudos de Dança no CEFD. Participou do Grupo Universitário de Dança, na época coordenado pela Professora Gisela Biancalana, ao lado de Alessandra Londero, Sheila Antunes, entre outros/as. A partir de monitorias e docência atuou em várias academias e escolas de dança da cidade de Santa Maria/RS. Também atuou como bailarino, coreógrafo e coordenador do Grupo Universitário de Dança até 2001. Além de dança para crianças e adolescentes, atuou como professor e coreógrafo de grupos da chamada terceira idade, os/as idosos/as. Vários alunos da Educação Física iniciaram e aprofundaram seus estudos de Dança no Grupo Universitário. Apresentações dentro e fora da UFSM sempre foram uma característica marcante do Grupo. A Professora Mara Rubia sempre esteve presente durante esse período, bem como na orientação do Trabalho de Conclusão de Curso de Gustavo Duarte, sob o tema Dança na Escola. De 2001 a 2003 Gustavo Duarte cursou o Mestrado na área de Educação, na UFSM, aprofundando suas pesquisas de Dança no contexto escolar, sob a orientação da professora Ingrid Baecker. Sua dissertação de Mestrado foi intitulada como: "O Dançar na Educação Física Escolar: a Experiência Estética no Movimento Humano". De 2004 a 2010 atuou no Centro Universitário Metodista do IPA, em Porto Alegre/RS, onde trabalhou com as disciplinas de Atividades Rítmicas e Dança para a Educação Física, e com projetos de extensão e pesquisa com dança para idosos. De 2010 a 2013 atuou no Curso de Dança do Centro de Artes da Universidade Federal de Pelotas/RS.

Nesse sentido, podemos destacar a relevância da formação em Dança proporcionada pelo CEFD, tanto na trajetória profissional quanto pessoal de Marcia Feijó, Luciane Sanchotene e Gustavo Duarte, todas/todos ex-alunas/os da Professora Mara Rubia. Esses professores seguiram atuando na Dança, tanto na docência quanto em suas pesquisas e em orientações acadêmicas. Assim como a formação inicial, a formação continuada em Dança mostrou-se muito relevante. Além da formação em diversos cursos de aperfeiçoamento, a inserção em projetos na comunidade, seja dentro ou fora da Escola, mostraram-se de fundamental importância para a qualidade da formação em Dança.

\section{Novo cenário: a criação do Curso de Dança no CEFD}

Os Cursos de Dança da UFSM foram criados a partir da longa tradição e do amor à Dança de duas professoras, lideranças na área, a professora Mara Rubia (Centro de Educação Física e Desportos/CEFD) e a professora Gisela Biancalana (Centro de Artes e Letras/CAL). 
Após um longo período de trabalho, de construção das concepções e diretrizes dos dois cursos, Licenciatura em Dança no CEFD e Bacharelado em Dança no CAL, no ano de 2013, ingressavam as primeiras turmas dos cursos de Dança na UFSM, com quinze vagas para cada curso.

No CEFD, inicialmente as professoras Mara Rubia e Maria Amélia Roth ministraram as disciplinas iniciais do curso, com o auxílio de professores de outros Centros, como o Centro de Ciências da Saúde e o Centro de Educação. No primeiro concurso docente do Curso de Dança Licenciatura ingressaram, no ano de 2014, os seguintes professores: Carlise Scalamato, Gustavo de Oliveira Duarte e Odailso Berté. No segundo concurso docente, a partir do ano de 2017, ingressaram respectivamente: Neila Baldi, Mônica Corrêa de Borba Barboza e Marcia Gonzalez Feijó.

Uma questão pioneira e relevante que merece destaque foi a primeira edição do PIBID DANÇA na UFSM, de 2014 a 2017, com parceria em duas escolas públicas da cidade: Edson Figueiredo e Vicente Farencena, onde a Professora Mara Rubia e o Professor Gustavo Duarte coordenaram cinco alunos bolsistas. O trabalho resultou no Livro: "Qual é a sua Dança? Dança para crianças e adolescentes” (DUARTE; SILVA, 2017), disponibilizado gratuitamente no site do Núcleo de Tecnologia Educacional (NTE) da UFSM (www.ufsm/nte).

Figura 10 - Capa do livro "Qual é a sua Dança? Dança para crianças e adolescentes”, 2017.

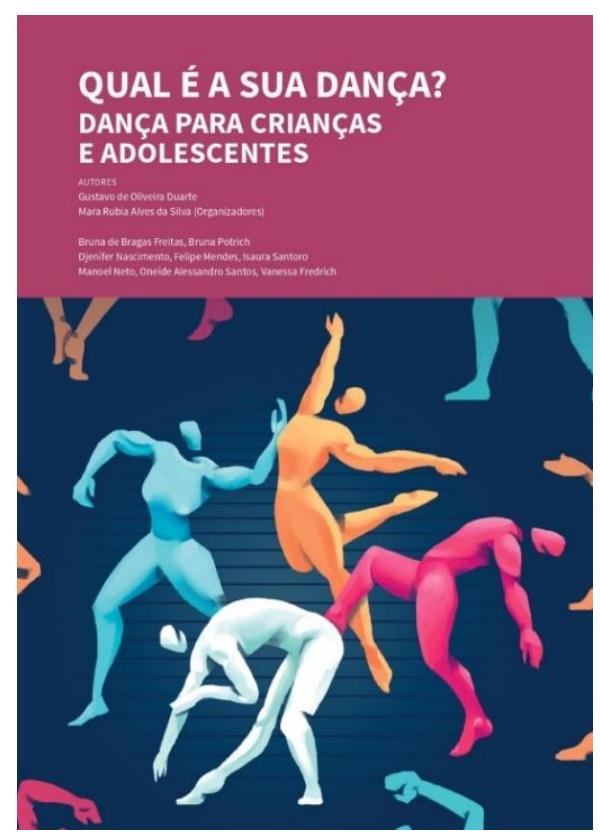

Fonte: www.ufsm/nte. 
A partir da iniciativa do Professor Odailso Berté, os primeiros professores do curso de Dança organizaram, em 2014, um Seminário sobre o ensino de Dança, o SEDANCE - "Seminário de Dança e Educação na Contemporaneidade". O mesmo foi desenvolvido por três edições.

Figura 11 - I SEDANCE

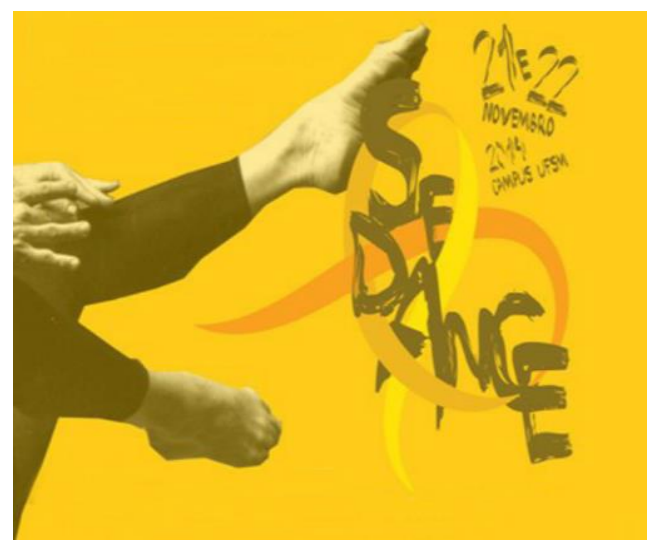

Fonte: Acervo de Odailso Berté

Figura 12 - II SEDANCE

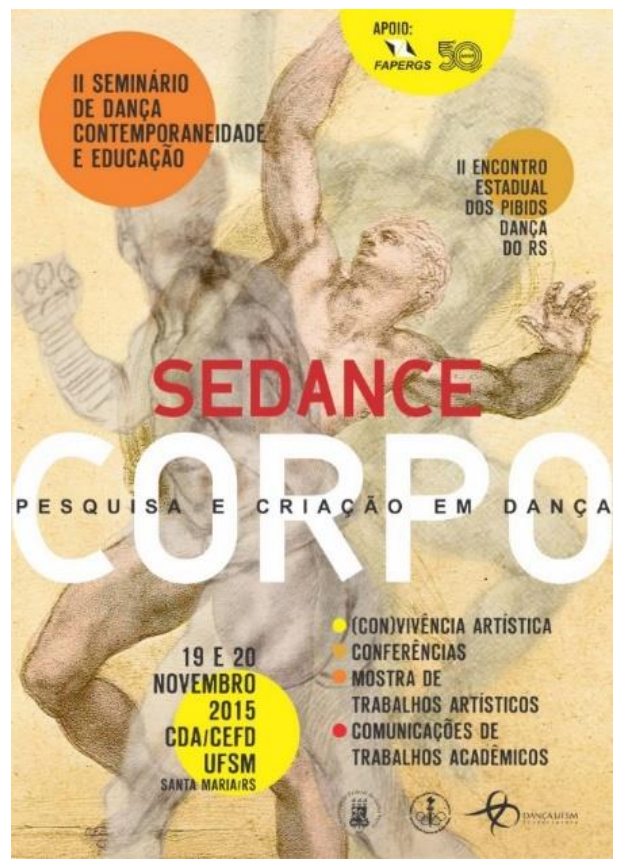

Fonte: Acervo de Odailso Berté 
Figura 13 - III SEDANCE
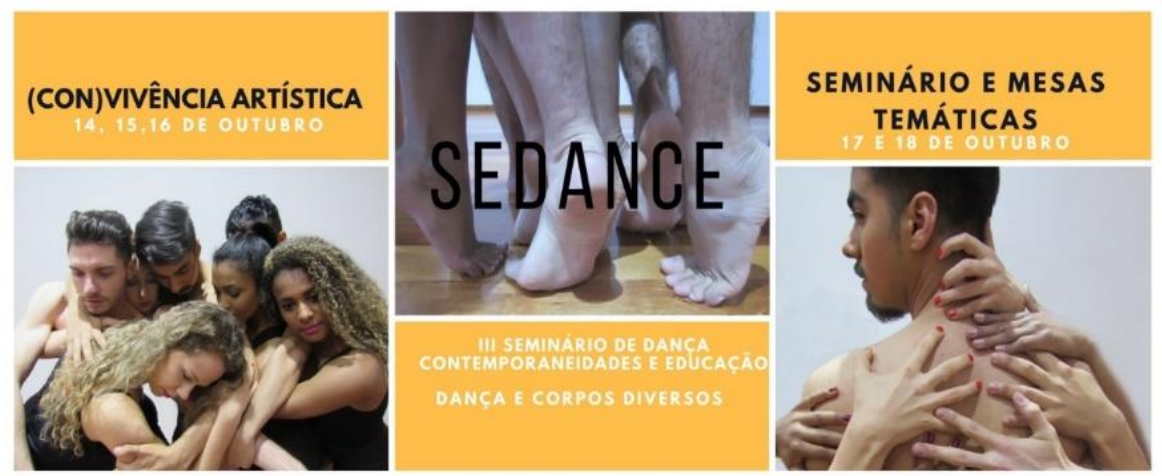

Fonte: Acervo de Odailso Berté

Mesmo no pouco tempo de atuação do Curso, um evento nacional já foi sediado pelo mesmo na UFSM - o IV Encontro Nacional de Pesquisadores em Dança da ANDA (Associação Nacional de Pesquisadores em Dança). O evento ocorreu no ano de 2015 com participação de artistas e pesquisadores de todo o País.

Figura 14 - Cartaz do IV Encontro Científico da ANDA (2015).

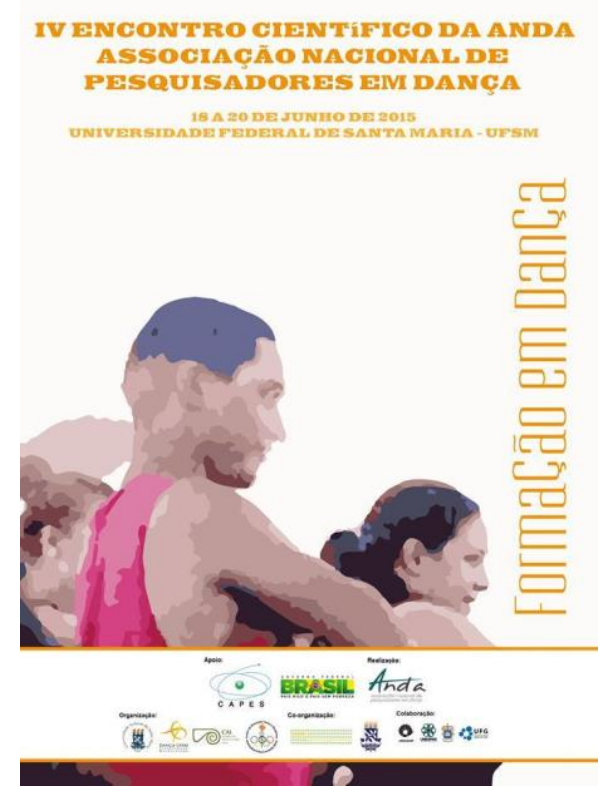

Fonte: Acervo de Odailso Berté

Recentemente, no ano de 2018, na sua primeira avaliação da Capes, o curso atingiu conceito quatro (4). Destacamos os primeiros Grupos e Laboratórios criados pelos docentes do Curso: Laboratório Investigativo de Criações Contemporâneas em Dança (LICCDA), coordenado pelo Professor Dr. Odailso 
Sivaldo Berté; o Grupo de Estudos em Educação, Dança e Cultura (GEEDAC) e o Laboratório de Improvisação e Coreografia (LICOR), coordenados pelo Professor Dr. Gustavo Duarte; e o Grupo de Pesquisa em Audiovisualidades da Dança (GPAD), coordenado pela Professora Dra. Carlise Scalamato.

Em 2019, de maneira inédita, professores dos dois cursos de Dança da UFSM, Licenciatura e Bacharelado, se reúnem no mesmo projeto e criam a UFSM Cia. de Dança, integrando o CEFD, com a Professora Marcia Feijó e o Professor Gustavo Duarte, ao Centro de Artes, com a Professora Tatiana Wonsik e a professora Silvia Wolff. A UFSM Cia. de Dança também conta com a colaboração da comunidade santa-mariense através da Royale Dança e Integração Social, sob a coordenação da Professora Dra. Daniela Nascimento.

A Cia. de Dança iniciou com vinte alunos/as de diferentes cursos da UFSM e da comunidade, já com alguma experiência em Dança. A Companhia busca contribuir na profissionalização dos/das bailarinos/as oferecendo aulas de balé clássico, dança moderna, dança teatro, pilates e preparação corporal. O primeiro trabalho da UFSM Cia. de Dança foi o "Ex-ah-lar" - um sopro de vida, dirigido pela Professora Dra. Tatiana Wonsik. Abaixo seguem fotos da estreia da Companhia no maior evento acadêmico da UFSM, em 2019, a Jornada Acadêmica Integrada (JAI).

Figura 15 - Apresentação da UFSM Cia. de Dança na Jornada Acadêmica Integrada/JAI. Local: Centro de Convenções UFSM, 2019.

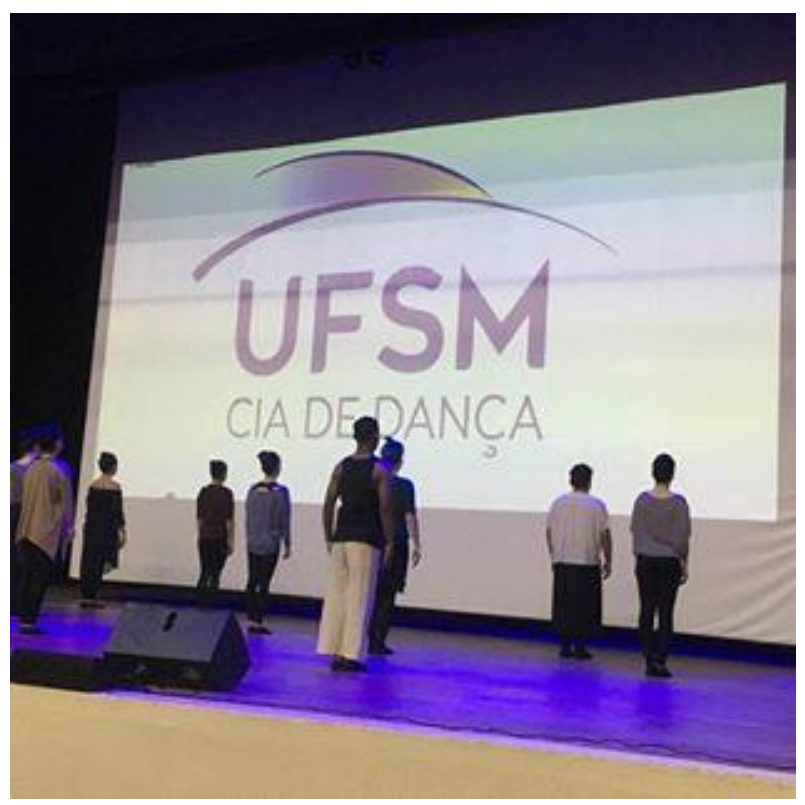

Fonte: Acervo de Gustavo Duarte. 
Figura 16 - UFSM Cia. de Dança, JAI/UFSM, 2019.

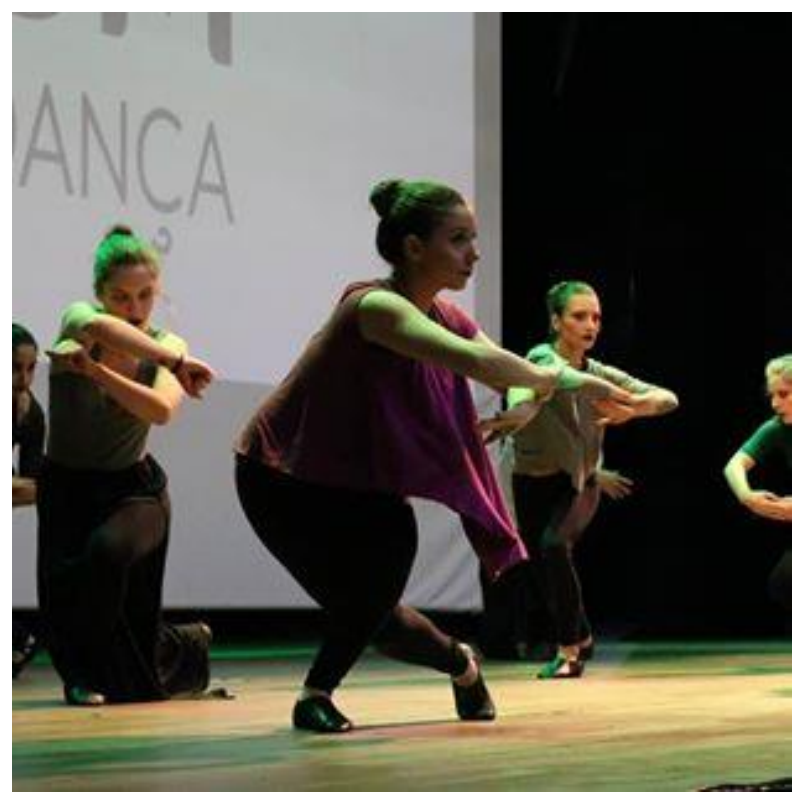

Fonte: Acervo de Gustavo Duarte.

Figura 17 - Logotipo da UFSM Cia. de Dança

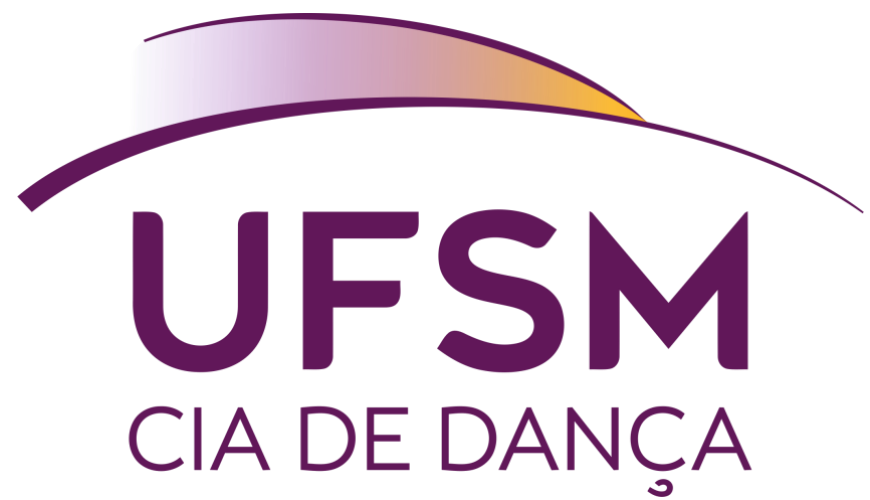

Fonte: Acervo de Gustavo Duarte.

\section{Considerações Finais}

Do individual para o coletivo. Assim compreendemos a Dança como componente curricular dos Cursos de Educação Física Licenciatura e Bacharelado, e, mais recentemente, como área de conhecimento no CEFD da Universidade Federal de Santa Maria.

Desde a primeira professora do CEFD a incentivar as áreas de Ginástica e Atividades Rítmicas, Professora Jacira Paixão, passando pela Professora Mara Rubia, com mais de trinta anos devotados à Dança, o amor e a dedicação dessas pioneiras contagiaram e multiplicaram-se por várias gerações de 
alunos/as e professores/as que continuam atuando com a docência e a criação em Dança, sobretudo nos Estados da região Sul do Brasil.

A partir de uma pesquisa (auto)biográfica, de processos investigativos de análise documental e do inventário de algumas passagens relevantes da "História da Dança" ocorridas no CEFD, homenageia-se essas duas professoras pioneiras na Dança do CEFD. A partir delas, vários trabalhos acadêmicos, festivais, eventos, cursos foram possíveis. Várias gerações de bailarinos/as e de professores/as de Dança se formaram.

Dado o exposto, após este recorte de alguns processos históricos relevantes do Centro de Educação Física e Desportos da Universidade Federal de Santa Maria em relação às áreas de Educação Física e Dança, ao revisitar algumas passagens históricas de seus alunos/as, professores/as e pesquisadores/as de vanguarda nesta instituição, a fim de homenagear o cinquentenário deste Centro de ensino, pode-se vislumbrar o início de uma nova etapa de formação em Dança.

De apenas uma ou duas disciplinas obrigatórias nos currículos dos Cursos de Educação Física, a Dança, desde 2013, passou a ser aprofundada em quatro anos de estudos por meio da graduação em Licenciatura em Dança do CEFD. Mediante a atuação do Núcleo Docente Estruturante (NDE) e do Colegiado do Curso de Dança, o currículo já se encontra na sua segunda versão, mais madura, mais coerente com as atuais políticas públicas, tanto da formação de educadores quanto das diretrizes curriculares dos cursos da área da Arte.

A criação de novos projetos de ensino, pesquisa e extensão, bem como de novos Grupos de Pesquisa e de Laboratórios, promoverá uma melhora significativa na formação em Dança. Projetos de Pós-Graduação em dança firmam-se como possibilidades concretas em um futuro próximo.

Vida longa à Dança. Vida longa ao CEFD.

\section{Referências}

DUARTE, G. O. O dançar na educação física escolar: a experiência estética no movimento humano. Revista Educação, Santa Maria, v. 32, n. 01, p. 241-254, jan./jun. 2007.

DUARTE, G. O.; SILVA, M. A. (Org.). Qual é a sua Dança? Dança para crianças e adolescente. 1 ed. Santa Maria, RS: UFSM/NTE, UAB, 2017. Disponível em: http://repositorio.ufsm.br/bitstream/handle/1/15831/Licenciatura_Danca_Qualasuadanca.pdf Acesso em: 15/07/2020. 
FEIJÓ, M. G. A Dança como Conteúdo integrante da Educação Física Escolar enquanto Corporeificação de Mundo Sensível. 1996. Dissertação (Mestrado em Ciência do Movimento Humano). Universidade Federal de Santa Maria, Santa Maria, 1996.

HASELBACH, B. Ästhetische Erzielung els beispiel der integration von tanz und bildender kunst. In: PAWELKE, R. Neue Sportkultur. Lichtenau: AOL, 1995, p. 298-304.

LABAN, R. Dança educativa moderna. São Paulo: Ícone, 1990.

MARQUES, I. A. Ensino de dança hoje: textos e contextos. São Paulo: Cortez, 1999.

\section{Como citar este artigo}

DUARTE, G. O.; FEIJÓ, M. G.; DARONCO, L.S. E.; SILVA, M. R. A. A Dança no CEFD: da formação em Educação Física à criação de um Curso de Graduação em Dança. Revista Kinesis, Santa Maria, Dossiê CEFD 50 anos, p.01-16, 2020.

* O presente trabalho não contou com apoio financeiro de nenhuma natureza para sua realização. 